\title{
Lean and agile metrics. Literature review and framework for measuring leagile supply chain
}

\section{Framework for measuring leagile supply chain}

\author{
Wojciech Domink Piotrowicz \\ Department of Marketing, Supply Chain Management and Social Responsibility, \\ Hanken School of Economics, Helsinki, Finland \\ Urszula Ryciuk \\ Faculty of Engineering Management, Biatystok University of Technology, \\ Biatystok, Poland, and \\ Maciej Szymczak \\ Institute of International Business and Economics, \\ Poznań University of Economics and Business, Poznan, Poland
}

\begin{abstract}
Purpose - The aim of this paper is to review metrics and develop a framework for measuring leagile supply chain. Metrics that are applicable in the lean, agile and leagile strategies are identified in the literature and are then combined into a framework that can reflect both agile and lean strategies - the leagile supply strategy. Design/methodology/approach - This work is based on the systematic literature review. Literature was collected, then lean and agile metrics were extracted, analysed, counted and grouped into the framework. Findings are compared against literature on leagile supply chain.

Findings - Findings indicate that there are sets of metrics specific to lean strategy, such as are processfocused, cost, productivity, inventory and delivery-based metrics, and specific to agile such as flexibility, responsiveness, information sharing and cooperation. There are also metrics common for both strategies; they are related to time, quality and customer satisfaction. Lean measures are tangible and focused on internal processes and products, while agile measures are targeted at external environment.

Practical implications - The framework could be used by practitioners as a starting point for performance system design.

Originality/value - There is a need to stop looking at lean and agile as separate and distinct supply strategies. Results of this research indicate that lean and agile are interlinked, both are focusing on customer satisfaction and quality. Applying a proposed set of metrics enables to design supply chain measurement system that reflects both strategies to measure leagile supply chain. The framework could be used by practitioners as a starting point for performance system design.
\end{abstract}

Keywords Lean and agile supply chain, Leagile supply chain, Supply chain performance measurement, Performance metrics, Supply chain strategy, Strategy

Paper type Conceptual paper

\section{Introduction}

Measuring supply chain performance is of growing importance as companies could not stay an isolated island, but they are part of supply chain that frequently compete against other chains. Simatupang and Sridharan (2008) define supply chain performance as the development and implementation of indicators for the overall assessment and the individual performance of each

(C) Wojciech Domink Piotrowicz, Urszula Ryciuk and Maciej Szymczak. Published by Emerald Publishing Limited. This article is published under the Creative Commons Attribution (CC BY 4.0) licence. Anyone may reproduce, distribute, translate and create derivative works of this article (for both commercial and non-commercial purposes), subject to full attribution to the original publication and authors. The full terms of this licence may be seen at http://creativecommons.org/licences/by/4.0/legalcode

Funding: The study was co-funded by the National Science Centre, Poland (2014/13/B/HS4/03293).
Received 10 November 2020 Revised 23 June 2021 Accepted 17 September 2021 
member of the supply chain. All entities involved should incorporate a broad and balanced approach to identify and measure issues which are vital for the whole supply chain. Performance measurement system should be aimed at supporting supply chain strategy implementation and enabling supply chain orchestration (Neely et al., 1995; Maestrini et al., 2018), and cover a wide range of metrics, including those that reflect sustainability (Piotrowicz and Cuthbertson, 2015). It is necessary to monitor strategy implementation and indicate actions for improvement. Performance measurement allows such monitoring; however, in practice the measurement process is very complex and difficult to implement.

The aim of this paper is to investigate links between supply chain strategy (lean and agile) and performance measurement metrics, linking three streams of literature: operations management, supply chain/logistics and performance measurement.

Narasimhan et al. (2006) pointed that lean and agile can be viewed as not only two distinct strategies but also as sets of different performance capabilities. The differences between both strategies would be reflected by the choice of performance metrics to monitor strategy implementation. This is in line with Piotrowicz and Cuthbertson (2015) who indicated that performance measurement systems should match specific context, including factors such as strategy and supply chain design. Lean and agile strategies, despite their popularity, are not well understood (Goldsby et al., 2006). There are gaps in the knowledge on performance measurement in lean, agile and leagile supply chain. Already in 1999 Gunasekaran called to develop and incorporate performance measurement into agile supply chain management (SCM). Naim et al. (2011) recommended exploring further performance characteristics of agile and lean strategies. Ciccullo et al. (2018) has advocated looking at lean, agility and sustainability as interconnected strategies. One could find in literature research suggesting some metrics for lean, agile or leagile strategy (Afonso et al., 2015; Moyano-Fuentes and Sacristán-Díaz, 2012; Arif-Uz-Zaman et al., 2014; Thanki and Thakkar, 2018; Sukwadi et al., 2013) but such work is non-exhaustive. Research frequently discusses lean, agile or leagile supply chain definitions, attributes, dimensions, conditions for applying selected strategies or compare them (i.e. MasonJones et al., 2000b; van Hoek et al., 2001; Agarwal et al., 2006; Naim et al., 2011). There is lack of proposition of set of metrics applicable in the lean, agile and leagile supply chain. Discussion is focused on performance characteristic, not on the measures. Thus this paper is closing this gap.

This paper aims to stimulate further research, reviewing literature and synthesizing findings, providing a framework for measuring both lean and agile parts of the supply chain, answering following question:

What are the main metrics that are applicable in the lean, agile and leagile strategies?

The paper is structured as follows. First, the methodology is presented, then concepts such as lean, agile with the focus on lean and agile and performance metrics are presented for each strategy, finally lean and agile metrics are discussed and integrated to create a framework that combines both group of metrics - the set of leagile performance metrics. Lastly, conclusions and recommendations for further research are listed.

\section{Background}

\subsection{Lean supply chain}

The term "lean" was first used by Krafcik (1988), then popularized by Womack et al. (1990), and can be summarized as "doing more with less" (Christopher et al., 2000). The lean concept is introduced when customer requirements exceed those of "traditional" cost, quality and speed, so the companies need to produce both low and high volume products at the same time (Yusuf et al., 2003). Arlbjørn et al. (2013) concluded that there are many interpretations of lean; therefore, it is possible to distinguish between lean philosophy, set or principles and tools and techniques. Hines et al. (2004) reviewed contemporary lean thinking since 1980 and noted that in the 1990s concepts such as lean enterprise and lean supply chain were introduced. Similar review was 
completed by Stone (2012); his analysis indicated that 2006-2009 literature was focused on the ways of how to measure leanness in organizations. Development of lean thinking, with focus on automotive production was traced by Holweg (2007), and then lean concept emerged in the service sector (Arlbjørn et al., 2013). As the main principles of lean SCM Jasti and Kodali (2015) identify: the information technology management, supplier management, elimination of waste, just in time production, customer relationship management, logistics management, top management commitment and continuous improvement.

Extensive review of the lean concept was completed by Moyano-Fuentes and SacristánDíaz (2012), who distinguished stream of literature focused on lean in value and supply chains. Lean supply chain emphasis is on waste identification, reduction and elimination of nonvalue-added activities (Carvalho and Cruz-Machado, 2011; Arif-Uz-Zaman et al., 2014). Lean supply chain is focused on cost reduction, flexibility and incremental improvements in products (Moyano-Fuentes and Sacristán-Díaz, 2012), however, as Gunasekaran (1999) pointed, lean is cost-efficient and productive, but it is not equal to be responsive.

\subsection{Agile supply chain}

The agile concept was widely discussed in the early 1990s; it is not a new idea though, as in 1982 Brown and Agnew already pointed that "many managers place too strong an emphasis on seeking to optimise", and they introduced the term and defined "corporate agility" as "the capacity to react quickly to changing circumstances" (Brown et al., 1982, p. 29). There is no agreement and commonly accepted definition of supply chain agility (Gligor and Holcomb, 2012). More about the definitions of agility manufacturing and supply contexts is included in works by Bernardes et al. (2009), Gligor and Holcomb (2012), Yusuf et al. (2014) and Eckstein et al. (2015).

The ability to quickly respond to the changing market needs - "changes in demand both in terms of volume and variety" (Christopher, 2000), opportunities or threats (Gligor et al.,2013) are key determinants of agility. Supply chain agility is "strategic ability that assists organizations rapidly to sense and respond to internal and external uncertainties via effective integration of supply chain relationships" (Fayezi et al., 2017). Agile supply chain focuses on the customer, cooperation and information management to manage uncertainty (van Hoek et al., 2001; Rimienè, 2011). Common elements in conceptualization of agility are: responsiveness, change as opportunity, flexibility, customer enrichment/customization, mobilization of core competences, integration, organizational structure and speed (Gligor and Holcomb, 2012; Khalili-Damghani, 2013). An agile system should respond to changes (Bernardes et al., 2009) in external environment and to customer requirements (Backhouse et al., 1999; van Hoek et al., 2001). The development of agile was traced by Huang et al. (2009), who identified four stages: initial concept building, agile manufacturing, agile supply chains which redirected post-1999 discussion from manufacturing and finally, approaches to achieve and measure agility.

In response to lack of consistency between definitions used in literature (Backhouse et al., 1999), the comparison between agility, flexibility and responsiveness was investigated by Bernardes et al. (2009). In agile supply chain relationship with suppliers should be flexible for both products and services, and at the same time, agile should fulfil customer needs and aim to keep leanness (Gunasekaran, 1999). Some of "waste" which normally should be removed in lean production might be important in the agile system (Mason-Jones et al, 2000b); this leads to the concept of leagility.

\subsection{Linking lean and agile - Leagile supply chain}

Leagility, which links both lean and agile, was introduced by Naylor et al. (1999), who realized that despite the "pull" system of Toyota Production System (TPS), still around 50\% of cars were in fact made to customer order, while the rest was made to stock; moreover, some of the 
cars were further customized after leaving Toyota factory (Naim et al., 2011). Soon it was agreed that both concepts could be merged; the "decoupling point" separates lean "push" part of supply chain, which is aimed at cost reduction, and agile "pull" which can fulfil diverse customer needs (Naim et al., 2011). Despite the differences between lean and agile it is possible to successfully link them in a total supply chain (Mason-Jones et al., 2000a), creating a "hybrid" approach (Goldsby et al., 2006). As Naim et al. (2011, p. 342) pointed, "lean and agile are distinct but interlinked concepts" and allow to have "best of both worlds": mix of cost and flexibility/service.

\subsection{Supply chain performance measurement}

This section introduces performance measurement with focus on supply chain performance measurement (SCPM) - more in reviews, e.g. Akyuz et al. (2009), Gopal et al. (2012), Gunasekaran et al. (2007), Morgan (2004), Shepherd et al. (2006), Taticchi et al. (2010), Balfaqih et al. (2016), Maestrini et al. (2017), evolution of performance measurement at the organizational level was also reviewed by Kennerley et al. (2002); Neely (2005), Neely et al. (1995). In the supply chain context for performance measurement different models and frameworks are applied, with the Balanced Scorecard and SCOR (chain operations reference model) being the most important approaches used in organizations (Akyuz et al., 2009; Piotrowicz and Cuthbertson, 2015).

Performance measurement is one of the key management activities within organization and is integrated with other actions such as planning, organization, motivation and control (Morgan, 2004). Performance metrics is a "verifiable measure, stated in qualitative or quantitative term, with respect to a reference point” (Melnyk et al., 2004, p. 211).

Metrics can be grouped into sets and create performance measurement system (Melnyk et al., 2004). Measures and metrics are necessary for full supply chain integration (Gunasekaran et al., 2001). Performance measurement provides links between strategy, execution and value creation (Melnyk et al., 2004). Performance measurement supports strategy formulation and clarification, management information, vertical and horizontal communication, decisions making and co-ordination, motivation and learning (Schmitz et al., 2004); thus the choice of metrics used to supply chain performance measurement is extremely important (Kim et al., 2012). Differences in the perception of supply chain performance across companies can lead to conflicting metrics being used in the same supply chain, and to difficulties in optimizing performance throughout the entire supply chain.

Gunasekaran et al. (2001) distinguished three levels of metrics: strategic, tactical and operational. Chan et al. (2003) distinguished metrics based on costs, customer responsiveness and productivity, while Elrod et al. (2013) who differentiated between costs, quality, time and flexibility.

Neely et al. (2005) define two dimensions related to the assessment of supply chain results: effectiveness and efficiency. Wu et al. (2014) propose the assessment of the supply chain including financial and non-financial indicators. Financial indicators are important in assessing the impact of operational changes on improving the financial condition of enterprises, while non-financial indicators refer to strategic goals and may relate, to increased flexibility or reduction of uncertainty (Wu et al., 2014).

\subsection{Matching supply chain strategy and external context}

Fisher (1997), Christopher and Towill (2000) and Aitken et al. (2003) point that supply chain strategies must match with product characteristics (product life cycle length, predictability of demand, product variety and market standards for lead times and service), competitive strategies and the environment. A lean supply chain concept works well where variety is low, demand is relatively stable and predictable; it is designed at creating a cost-efficient supply chain, with a focus on reducing inventory lead times and waste (Agarwal et al., 2006; 
Wang et al., 2004). Qi et al. (2009) proved that agile strategy is rather implemented for innovative products, while lean rather involves long product life cycle, low profit margin, low variety and long lead times, and the range in between the values of efficiency versus responsiveness or lean versus agile can be used to categorize the supply chain into leagile or hybrid (Birhanu et al., 2014). As stressed by Christopher et al. (2006), it is important to match supply chain strategy and supply chain characteristics, such as lead time (short/long) and demand characteristics (predictable/unpredictable).

According to Fayezi et al. (2017), supply chain strategy should match various organizational characteristics of a product (industry, company size, geographical location) and consider their changes and development. Approaches to the coexistence of lean and agile strategies in supply chain are dependent on market conditions and operating environment (Mason-Jones et al., 2000a; Christopher and Towill, 2001; Bruce, 2004; Goldsby, 2006; Madhani, 2017):

(1) The Pareto (80:20 rule) curve approach with lean strategy for $20 \%$ of products (fastmoving, with stable demand and make-to-stock production) and agile strategy for $80 \%$ of products (slow movers, more volatile and make-to-order production);

(2) The de-coupling point approach with lean methods up to the de-coupling point and agile methods beyond it, assuming based on planning operating cost-effectively upstream and responsively satisfying customer downstream supply chain with the postponement of final production until order from a customer is known;

(3) Surge/base demand separation approach based on lean strategy for more forecastable demand and agile for less predictable demand, cost-effective operation.

A tool to assess the level of supply chain leagility was elaborated by Rahiminezhad Galankashi and Helmi (2016). The authors as main legality drivers point cost quality service level and lead-time. The method to calculate Leagility Index could also be found in Banerjee and Ganjeizadeh (2017).

According to literature, SCPM should be aligned with context in which it operates (Cuthbertson and Piotrowicz, 2011) and with supply chain strategy (Akyuz et al., 2009; Chan et al., 2003a; Lambert et al., 2001; Morgan, 2004), thus it is possible to expect that there are specific metrics to monitor both lean and agile supply chain. Therefore, the following research question is proposed:

$R Q 1$. What are the main metrics that are applicable in the lean, agile and leagile strategy?

\section{Research methodology}

The main purpose of the research was to develop the framework for measuring leagile supply chain performance. The study is based on literature review (Figure 1). The methodology for the literature review is adapted from Okoli (2015).

First procedure for literature review was elaborated - the choice of databases and criteria for paper inclusion were settled. In the study, the academic journal articles available in the EBSCO, Elsevier and Emerald full-text databases were used. The articles containing terms "lean", "agile" or "leagile" and "supply chain" in the title, abstract or keywords (using different combinations) were selected. The peer-reviewed papers, published in English, from 1990 up to the end of 2020 were chosen. Then titles, keywords, abstracts were checked. This stage enabled the removal of unrelated literature and reduced the number of articles to 155 (Table 1).

At the next stage, papers were taken for detailed screening. This included identifying and classifying metrics listed in 62 papers. Then metrics that measure similar performance aspect were coded, grouped and counted. Afterwards metrics in groups were divided according to count numbers (number of times when metric was listed as specific for lean or agile supply
Framework for measuring leagile supply chain

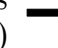




\section{IJPPM}

Figure 1.

The methodology adapted for the study

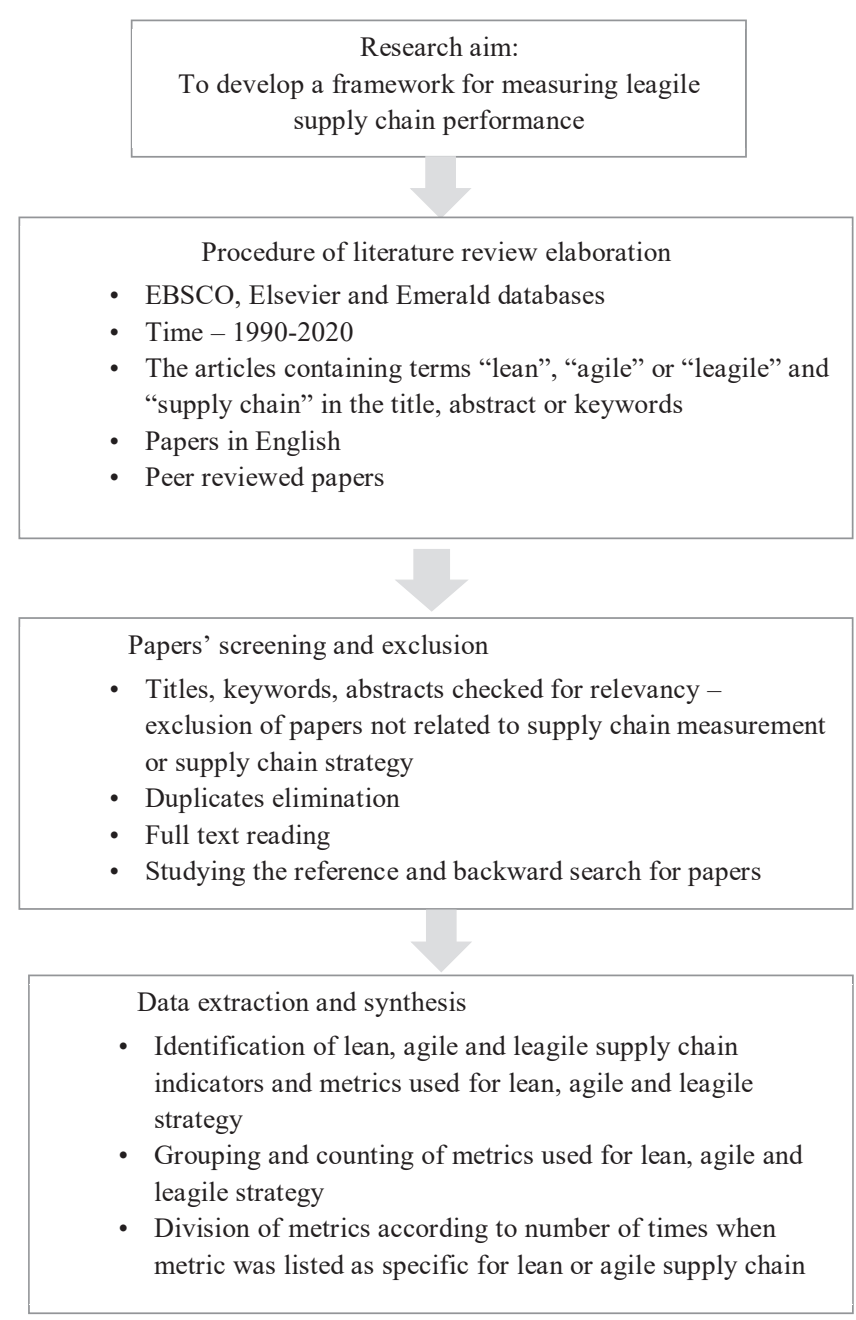

chain). Groups of metrics were then set in order, as presented in the final framework. Findings were compared with earlier literature on the topic.

\section{Framework for measuring leagile supply chain performance}

4.1 Performance criteria of lean supply chain

Performance focus of lean was changing over time: in the mid-1990s it was just quality, then quality, costs and delivery were the point of interest, moving finally to capabilities at the system level. Metrics concentrate on cost, cost efficiency (Gunasekaran, 1999; Gunasekaran et al., 2001) or productivity (Kuhlang et al., 2011; Malmbrandt et al., 2013) (Table 1). Arif-UzZaman et al. (2014) propose such metrics as: profit/piece, effectiveness of master production, cost of goods, manufacturing cost, overhead cost or total logistic cost. As lean supply chain emphasis is on waste identification and reduction, such metrics as inventory turnover rate 


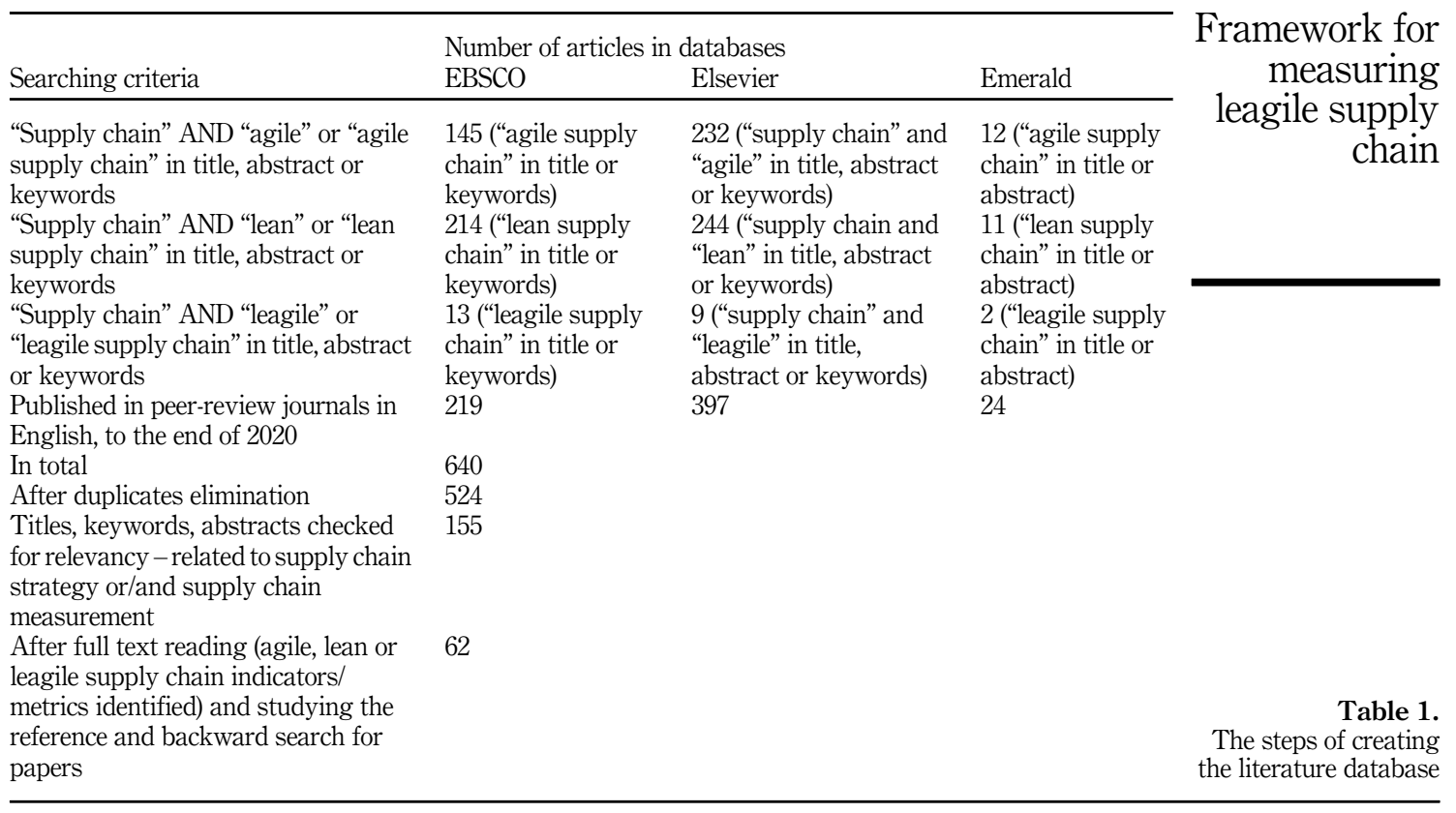

(Gunasekaran et al., 2001; Malmbrandt et al., 2013) or stock level (Govindan et al., 2015; Malmbrandt et al., 2013) are pointed.

Concentration merely on costs in lean was critiqued by Hines et al. (2004) who stated that such an approach was misinterpretation of "value" which was perceived as equal to "lower costs", while in fact value is composed of both cost reduction and increase in service offered to customers. Service level and customer satisfaction in lean supply chain are emphasized by Moyano-Fuentes and Sacristán-Díaz (2012), Agarwal et al. (2006), Mason-Jones et al. (2000b). Cost and quality in lean supply chain are underlined by Naylor et al. (1999); Mason-Jones et al. (2000a); Sukwadi et al. (2013) and Agarwal et al. (2006). Quality is interpreted as measure related not only to the quality of delivered goods but also to customer satisfaction, buyersuppliers relationship level, quality of delivered goods and accuracy of forecasting techniques (Arif-Uz-Zaman et al., 2014). Arif-Uz-Zaman et al. (2014) also pointed time and metrics as total cycle time, purchase order cycle time, production time/piece and delivery lead time as important lean indicators. Lead time is listed by Kuhlang et al. (2011), Malmbrandt et al. (2013), Naim et al. (2011), Naylor et al. (1999), Sukwadi et al. (2013) and Agarwal et al. (2006).

Most of the performance metrics of lean have been developed for manufacturing (Sangwa and Sangwan, 2018). For measuring operational performance in lean services, Malmbrandt et al. (2013) listed the following: productivity, lead time, inventory turnover rate, quality and stock level. A positive link between the successful implementation of lean in manufacturing and usage of non-financial metrics was also identified (Fullerton et al., 2009), as Meade et al. (2010) pointed the use of lean traditional financial metrics is not enough.

\subsection{Performance criteria of agile supply chain}

Christopher et al. (2000) listed the following key business indicators in agile supply chain: quality, lead time, cost and availability. According to Lin et al. (2006), four main capabilities 
that agile supply chain should include are: responsiveness, competency, flexibility/ adaptability and quickness/speed. Responsiveness is defined as sensing, anticipating changes, the ability to identify, respond to and recover from changes quickly and reactively (Fayezi et al., 2017; Zhang and Sharifi, 2000; Aitken et al., 2005; Tarafdar and Qrunfleh, 2017; Khalili-Damghani and Madjid Tavana, 2013; Gurahoo and Salisbury, 2018). Frequently (and sometimes interchangeably to responsiveness) mentioned are alertness, - defined as the ability to quickly detect changes, opportunities and threats (Gligor et al., 2013; Li et al., 2008) quickness/speed - the ability to complete an activity as quickly as possible (Christopher, 2000; Zhang and Sharifi, 2000) - or swiftness, understood as the ability to implement decisions quickly (Gligor et al., 2013). These indicators of the agile supply chain enable its flexibility, - scope, time and cost, re-configurability (Fayezi et al., 2017) or, in longer perspective, adaptability - the ability to sense long-term, fundamental changes in the supply chain and market environment (Eckstein et al., 2015).

Agility was initially described based on speed and an efficient response to changes and uncertainties; additional dimensions such as quality, knowledge management and cooperation were added later (Rimienè, 2011). The indicator of opportunity seeking longterm success of the agile supply chain is named as proactiveness (Fayezi et al., 2017). Some authors (Khalili-Damghani and Madjid Tavana, 2013; Gligor et al., 2015; Lin et al., 2006; Naylor et al., 1999; Yusuf et al., 2014; Mason-Jones et al., 2000a, b) claim that agility is primarily tied to service level, customer sensitivity, customer satisfaction or the extent to which customer-related objectives have been met (customer effectiveness) and could be achieved, e.g. "by understanding, analyzing and managing customer expectations, and effectively and efficiently dealing with complaints" (Al Kahtani et al., 2019).

Joint planning, process integration, close relationships and open communication in agile supply chain are a priority. Agile supply chain needs access to relevant information characterized by wide communication, information sharing and high level of information systems and technology usage (Tarafdar and Qrunfleh, 2017; Fayezi et al., 2017; Gurahoo and Salisbury, 2018; Lin et al., 2006; Mirghafoori et al., 2017). Level of information sharing could be measured by types of information shared between supply chain partners, such as demand, inventory levels and forecasts (Yang and Zhang, 2013). The level of sharing the data and technology usage - based on bar codes or RFID, big data or business analytics - is crucial (Szymczak et al., 2018) and should be monitored and measured. Data accessibility (Gligor and Holcomb, 2012; Gligor et al., 2013), real-time date exchange (Ahn et al., 2012), information integration (Khalili-Damghani and Madjid Tavana, 2013) and visibility (Braunscheidel and Suresh, 2009) are also the agile supply chain indicators. High level of information sharing with supply chain partners is supporting; market trends monitoring, quicker response to changing demands, as well as planning and introduction of new products and services (Tarafdar and Qrunfleh, 2017). Information sharing is desirable for lean supply chain but it is obligatory for agile supply chain (Mason-Jones et al., 2000a).

\subsection{Comparing performance focus of lean and agile supply chain}

Table 2 presents performance dimensions and metrics proposed in literature (listed in 62 papers) for lean and agile supply chains. Based on the metrics distributed in the table, it is possible to observe that some of them are specific only to one of the strategies. Metrics dominant in lean supply chain include productivity, inventory turnover rate, inventory level, cost (notably cost of goods, manufacturing cost or total logistic cost), profitability and efficiency. Metrics characteristic for agile strategy are even more pronounced. Competency, responsiveness, decisiveness, alertness, quickness, market sensitivity, innovativeness, flexibility, cooperation, information sharing, integration and data accessibility are widespread. Metrics for both agile and lean are overlapping and include lead time, quality, service level or customer satisfaction. 


\begin{tabular}{|c|c|c|c|c|}
\hline & Metric & Lean & Agile & Framework to \\
\hline \multirow[t]{2}{*}{ Productivity } & Productivity & $\begin{array}{l}\text { van Hoek et al. } \\
(2001) \\
\text { Kuhlang et al. } \\
(2011) \\
\text { Malmbrandt et al. } \\
(2013)\end{array}$ & Al Kahtani et al. (2019) & $\begin{array}{r}\text { leagile supply } \\
\text { chain }\end{array}$ \\
\hline & Organizational productivity (time and cost) & & \multirow[t]{4}{*}{ Al Kahtani et al. (2019) } & \\
\hline \multirow[t]{5}{*}{ Inventory } & Inventory turnover rate & $\begin{array}{l}\text { Gunasekaran et al. } \\
(2001) \\
\text { Malmbrandt et al. } \\
\text { (2013) } \\
\text { Marodin et al. (2017) }\end{array}$ & & \\
\hline & Inventory/stock level & Melton (2005) & & \\
\hline & & $\begin{array}{l}\text { Ugochukwu et al. } \\
(2012) \\
\text { Malmbrandt et al. } \\
\text { (2013) } \\
\text { Govindan et al. } \\
\text { (2015) } \\
\text { Frazzon et al. (2017) } \\
\text { Tortorella } \text { et al. } \\
\text { (2018) }\end{array}$ & & \\
\hline & Inventory/stock management & $\begin{array}{l}\text { Packowski and } \\
\text { Francas (2013) }\end{array}$ & Khan et al. (2009) & \\
\hline & Availability & & Christopher et al. (2000) & \\
\hline \multirow[t]{23}{*}{ Time } & Order cycle time & $\begin{array}{l}\text { Gunasekaran } \\
\text { (2001) }\end{array}$ & & \\
\hline & Total cycle time & $\begin{array}{l}\text { Arif-Uz-Zaman } \\
\text { et al. }(2014)\end{array}$ & Swafford (2008) & \\
\hline & $\begin{array}{l}\text { Time (production and technology preparation time, } \\
\text { period of manufacturing, speed of products design } \\
\text { and short development cycle time) }\end{array}$ & & $\begin{array}{l}\text { Khalili-Damghani and } \\
\text { Madjid Tavana (2013) }\end{array}$ & \\
\hline & $\begin{array}{l}\text { Time (total cycle time, purchase order cycle time, } \\
\text { production time/piece, delivery lead time) }\end{array}$ & $\begin{array}{l}\text { Arif-Uz-Zaman } \\
\text { et al. (2014) } \\
\text { Afonso et al. (2015) }\end{array}$ & & \\
\hline & Lead time & Naylor et al. (1999) & Naylor et al. (1999) & \\
\hline & & Mason-Jones et al. & Christopher et al. (2000) & \\
\hline & & $(2000 \mathrm{a})$ & Mason-Jones et al. (2000a) & \\
\hline & & Christopher and & Christopher and Towill & \\
\hline & & Towill (2001) & $\begin{array}{l}(2001) \\
\text { Suafford (2008) }\end{array}$ & \\
\hline & & $\begin{array}{l}\text { Melton (2005) } \\
\text { Agarwal et al. }\end{array}$ & $\begin{array}{l}\text { Swafford (2008) } \\
\text { Naim et al. (2011) }\end{array}$ & \\
\hline & & $(2006)$ & Aronsson et al. (2011) & \\
\hline & & $\begin{array}{l}\text { Kuhlang et al. } \\
(2011)\end{array}$ & & \\
\hline & & Naim et al. (2011) & & \\
\hline & & $\begin{array}{l}\text { Malmbrandt et al. } \\
\text { (2013) }\end{array}$ & & \\
\hline & & Sukwadi et al. & & \\
\hline & & $(2013)$ & & \\
\hline & & Arif-Uz-Zaman & & \\
\hline & & et al. (2014) & & \\
\hline & & Frazzon et al. (2017) & & \\
\hline & & $\begin{array}{l}\text { Packowski and } \\
\text { Francas (2013) }\end{array}$ & & \\
\hline & Supply lead time & Tortorella et al. & & \\
\hline & & $(2018)$ & & Table 2. \\
\hline & & & (continued) & $\begin{array}{l}\text { Lean and agile and } \\
\text { supply chain metrics }\end{array}$ \\
\hline
\end{tabular}




\begin{tabular}{|c|c|c|c|}
\hline & Metric & Lean & Agile \\
\hline \multirow[t]{4}{*}{ Quality } & Quality & $\begin{array}{l}\text { Naylor et al. (1999) } \\
\text { Mason-Jones et al. } \\
\text { (2000a) } \\
\text { van Hoek } \text { et al. } \\
\text { (2001) } \\
\text { Hines } \text { et al. (2004) } \\
\text { Melton (2005) } \\
\text { Agarwal } \text { et al. } \\
\text { (2006) } \\
\text { Fening } \text { et al. (2008) } \\
\text { Wee and Wu (2009) } \\
\text { Naim et al. (2011) } \\
\text { Ugochukwu } \text { et al. } \\
\text { (2012) } \\
\text { Malmbrandt et al. } \\
\text { (2013) } \\
\text { Sukwadi et al. } \\
\text { (2013) } \\
\text { Afonso et al. (2015) } \\
\text { Govindan } \text { et al. } \\
\text { (2015) } \\
\text { Marodin } \text { et al. (2017) } \\
\text { Gurahoo and } \\
\text { Salisbury (2018) } \\
\text { Tortorella et al. } \\
\text { (2018) }\end{array}$ & $\begin{array}{l}\text { Yusuf et al. (1999) } \\
\text { Naylor } \text { et al. (1999) } \\
\text { Christopher } \text { et al. (2000) } \\
\text { Mason-Jones } \text { et al. }(2000 \mathrm{a}) \\
\text { Naim } \text { et al. }(2011) \\
\text { Yusuf et al. }(2014) \\
\text { Rahimi et al. (2020) }\end{array}$ \\
\hline & Product quality & $\begin{array}{l}\text { Christopher and } \\
\text { Towill (2001) }\end{array}$ & $\begin{array}{l}\text { Christopher and Towill } \\
\text { (2001) }\end{array}$ \\
\hline & $\begin{array}{l}\text { Quality (quality over product life, first time right } \\
\text { decision, and products and services with high } \\
\text { information and value-added contents) }\end{array}$ & & $\begin{array}{l}\text { Khalili-Damghani and } \\
\text { Madjid Tavana (2013) }\end{array}$ \\
\hline & $\begin{array}{l}\text { Quality (customer satisfaction, buyer-suppliers } \\
\text { relationship level, quality of delivered goods and } \\
\text { accuracy of forecasting techniques) }\end{array}$ & $\begin{array}{l}\text { Arif-Uz-Zaman } \\
\text { et al. (2014) }\end{array}$ & \\
\hline \multirow[t]{4}{*}{ Delivery } & Delivery capability & Hines et al. (2004) & \multirow[t]{4}{*}{$\begin{array}{l}\text { Swafford (2008) } \\
\text { Yusuf et al. (2014) }\end{array}$} \\
\hline & Delivery time & $\begin{array}{l}\text { Ugochukwu et al. } \\
\text { (2012) }\end{array}$ & \\
\hline & Delivery performance & $\begin{array}{l}\text { Thanki and } \\
\text { Thakkar (2018) }\end{array}$ & \\
\hline & Delivery service level & $\begin{array}{l}\text { Frazzon et al. }(2017) \\
\text { Tortorella et al. } \\
\text { (2018) }\end{array}$ & \\
\hline \multirow[t]{7}{*}{$\begin{array}{l}\text { Customer service } \\
\text { level }\end{array}$} & \multirow[t]{6}{*}{ Service level } & $\begin{array}{l}\text { Mason-Jones et al. } \\
\text { (2000a) }\end{array}$ & Naylor et al. (1999) \\
\hline & & Hines et al. (2004) & Mason-Jones et al. (2000a) \\
\hline & & Melton (2005) & $\begin{array}{l}\text { Christopher and Towill } \\
\text { (2001) }\end{array}$ \\
\hline & & $\begin{array}{l}\text { Agarwal et al. } \\
(2006)\end{array}$ & Swafford (2008) \\
\hline & & $\begin{array}{l}\text { Moyano-Fuentes } \\
\text { et al. }(2012)\end{array}$ & Kumar et al. (2019) \\
\hline & & $\begin{array}{l}\text { Packowski and } \\
\text { Francas (2013) }\end{array}$ & Aronsson et al. (2011) \\
\hline & $\begin{array}{l}\text { Service level (customer satisfaction, employee } \\
\text { satisfaction and customer enrichment) }\end{array}$ & & $\begin{array}{l}\text { Khalili-Damghani and } \\
\text { Madjid Tavana (2013) } \\
\text { Wu (2017) }\end{array}$ \\
\hline
\end{tabular}

Table 2. 


\begin{tabular}{|c|c|c|c|c|}
\hline & Metric & Lean & Agile & Framework for \\
\hline & Customer satisfaction & $\begin{array}{l}\text { Mason-Jones et al. } \\
\text { (2000b) } \\
\text { Gunasekaran } \\
\text { (2001) } \\
\text { Moyano-Fuentes } \\
\text { et al. (2012) } \\
\text { Ugochukwu et al. } \\
\text { (2012) }\end{array}$ & $\begin{array}{l}\text { Mason-Jones et al. (2000b) } \\
\text { Patel et al. (2017) }\end{array}$ & $\begin{array}{r}\text { leagile supply } \\
\text { chain }\end{array}$ \\
\hline & Customer effectiveness & & Gligor et al. (2015) & \\
\hline \multirow[t]{20}{*}{ Cost } & Cost & Naylor et al. (1999) & Christopher et al. (2000) & \\
\hline & & Mason-Jones et al. & Mason-Jones et al. (2000a) & \\
\hline & & $(2000 \mathrm{a})$ & Khalili-Damghani and & \\
\hline & & Gunasekaran et al. & Madjid Tavana (2013) & \\
\hline & & Christopher and & & \\
\hline & & Towill (2001) & & \\
\hline & & Hines et al. (2004) & & \\
\hline & & Melton (2005) & & \\
\hline & & $\begin{array}{l}\text { Agarwal et al. } \\
(2006)\end{array}$ & & \\
\hline & & $\begin{array}{l}\text { Aronsson et al. } \\
\text { (2011) }\end{array}$ & & \\
\hline & & $\begin{array}{l}\text { Ugochukwu et al. } \\
\text { (2012) }\end{array}$ & & \\
\hline & & Sukwadi et al. & & \\
\hline & & $(2013)$ & & \\
\hline & & Afonso et al. (2015) & & \\
\hline & & Thanki and & & \\
\hline & & Thakkar (2018) & & \\
\hline & & Kumar et al. (2019) & & \\
\hline & $\begin{array}{l}\text { Cost (cost of goods, manufacturing cost, overhead } \\
\text { cost, total logistic cost and price) }\end{array}$ & $\begin{array}{l}\text { Arif-Uz-Zaman } \\
\text { et al. }(2014)\end{array}$ & & \\
\hline & Costs with supply and raw material & $\begin{array}{l}\text { Tortorella et al. } \\
\text { (2018) }\end{array}$ & & \\
\hline & Product cost & Wee and $\mathrm{Wu}(2009)$ & & \\
\hline \multirow[t]{5}{*}{ Efficiency } & Effectiveness of master production & $\begin{array}{l}\text { Arif-Uz-Zaman } \\
\text { et al. }(2014)\end{array}$ & & \\
\hline & Efficiency/cost efficiency & $\begin{array}{l}\text { Gunasekaran } \\
\text { (1999) }\end{array}$ & Gunasekaran (1999) & \\
\hline & & $\begin{array}{l}\text { Gunasekaran et al. } \\
\text { (2001) }\end{array}$ & & \\
\hline & & Frazzon et al. (2017) & & \\
\hline & & $\begin{array}{l}\text { Ugochukwu et al. } \\
\text { (2012) }\end{array}$ & & \\
\hline \multirow[t]{4}{*}{ Profitability } & Profit/piece & Arif-Uz-Zaman & & \\
\hline & & et al. (2014) & & \\
\hline & Profitability & Thanki and & & \\
\hline & Comnetency & Thakkar (2018) & & \\
\hline \multirow{6}{*}{ Competency } & Competency & & Zhang and Sharifi (2000) & \\
\hline & & & Jain et al. $(2008)$ & \\
\hline & & & Khalili-Damghani and & \\
\hline & & & Madjid Tavana (2013) & \\
\hline & & & Mehralian et al. (2015) & \\
\hline & & & (continued) & Table 2. \\
\hline
\end{tabular}




\begin{tabular}{|c|c|c|c|}
\hline & Metric & Lean & Agile \\
\hline \multirow[t]{2}{*}{$\begin{array}{l}\text { Responsiveness/ } \\
\text { Alertness }\end{array}$} & $\begin{array}{l}\text { Decisiveness } \\
\text { Alertness } \\
\text { Responsiveness }\end{array}$ & & $\begin{array}{l}\text { Gligor } \text { et al. (2013) } \\
\text { Gligor } \text { et al. (2013) } \\
\text { Christopher } \text { et al. (2004) } \\
\text { Christopher } \text { et al. (2006) } \\
\text { Lin } \text { et al. (2006) } \\
\text { Narasimhan } \text { et al. (2006) } \\
\text { Jain } \text { et al. (2008) } \\
\text { Swafford (2008) } \\
\text { Braunscheidel } \text { et al. } \\
\text { (2009) } \\
\text { Khalili-Damghani and } \\
\text { Madjid Tavana (2013) } \\
\text { Mehralian } \text { et al. (2015) } \\
\text { Matawale } \text { et al. (2016) } \\
\text { Fayezi et al. (2017) } \\
\text { Tarafdar and Qrunfleh } \\
\text { (2017) }\end{array}$ \\
\hline & Responsiveness/alertness & $\begin{array}{l}\text { Gunasekaran } \\
\text { (1999) }\end{array}$ & $\begin{array}{l}\text { Gunasekaran (1999) } \\
\text { Zhang and Sharifi (2000) } \\
\text { Aitken } \text { et al. (2005) } \\
\text { Li et al. (2008) } \\
\text { Li et al. (2009) } \\
\text { Sukwadi et al. (2013) } \\
\text { Fayezi et al. (2017) } \\
\text { Gurahoo and Salisbury } \\
\text { (2018) }\end{array}$ \\
\hline Quickness/speed & $\begin{array}{l}\text { Visibility and velocity } \\
\text { Quick response }\end{array}$ & $\begin{array}{l}\text { Gunasekaran et al. } \\
\text { (2001) }\end{array}$ & Saeed et al. (2019) \\
\hline & Quickness/speed & & $\begin{array}{l}\text { Christopher (2000) } \\
\text { Zhang and Sharifi (2000) } \\
\text { Lin et al. (2006) } \\
\text { Jain et al. (2008) } \\
\text { Yusuf et al. (2014) } \\
\text { Mirghafoori et al. (2017) } \\
\text { Gurahoo and Salisbury } \\
\text { (2018) } \\
\text { Rahimi et al. (2020) }\end{array}$ \\
\hline & Quickness/swiftness & & $\begin{array}{l}\text { Khalili-Damghani and } \\
\text { Madjid Tavana (2013) } \\
\text { Mehralian et al. (2015) } \\
\text { Fayezi } \text { et al. }(2017) \\
\text { Gligor } \text { et al. }(2013) \\
\text { Gligor } \text { et al. (2013) }\end{array}$ \\
\hline $\begin{array}{l}\text { Customer/market } \\
\text { sensitivity }\end{array}$ & $\begin{array}{l}\text { Customization } \\
\text { Innovativeness/new product introduction }\end{array}$ & & $\begin{array}{l}\text { Lin et al. (2006) } \\
\text { Khalili-Damghani and } \\
\text { Madjid Tavana (2013) } \\
\text { Patel } \text { et al. (2017) } \\
\text { Al Kahtani } \text { et al. (2019) } \\
\text { Narasimhan } \text { et al. (2006) } \\
\text { Swafford (2008) } \\
\text { Narasimhan } \text { et al. (2006) } \\
\text { Swafford (2008) } \\
\text { Yusuf et al. (2014) } \\
\text { Rahimi } \text { et al. (2020) }\end{array}$ \\
\hline
\end{tabular}

Table 2. 


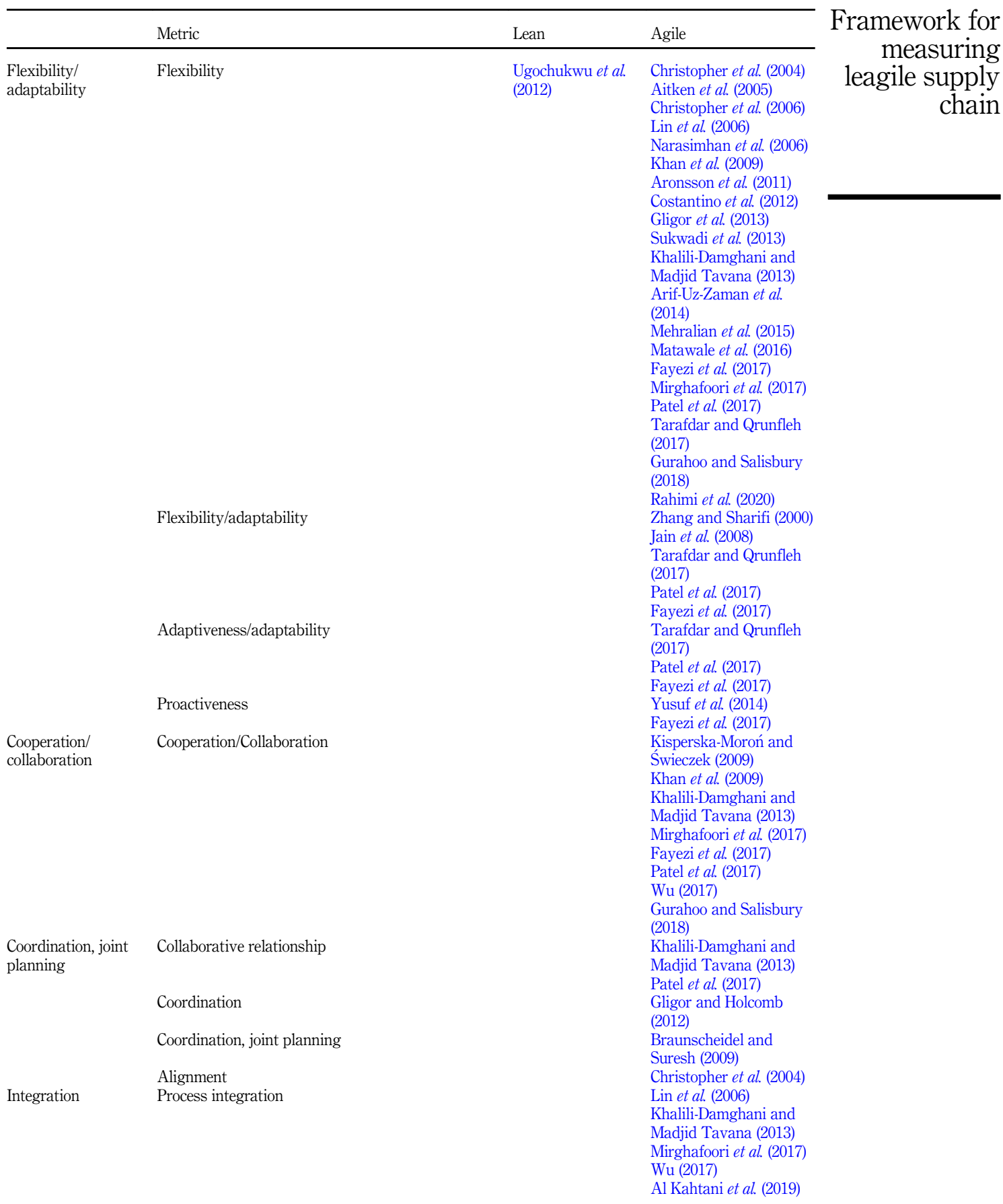




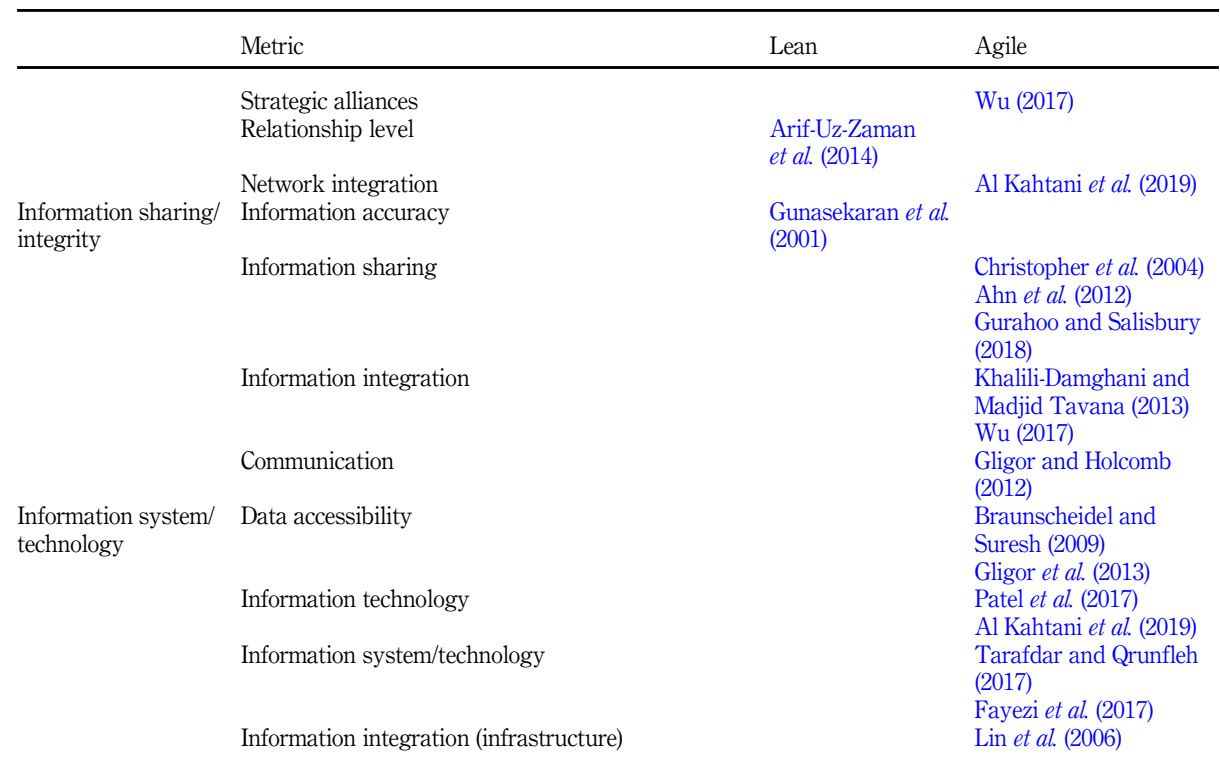

In the next step metrics that measure similar performance aspect were grouped and counted (Figure 2). It is possible to notice that there are metrics groups such as:

(1) Cost, Profitability, Productivity, Efficiency, Inventory Management and Deliverybased dominant for lean (with Cost and Inventory Management the most meaningful);

(2) Time, Quality and Customer-based metrics (including customer satisfaction and service level), common for both lean and agile;

(3) Metrics related to Responsiveness/alertness, Competency, Market sensitivity, Quickness/speed, Flexibility/Adaptability, Information sharing and Information technologies, Integration, Coordination and Cooperation, dominant for agile (pointing Flexibility/Adaptability and Responsiveness/alertness as the most noticeable).

Usage of all the metrics that are lean and agile specific, together with common metrics, allows to measure lean and agile parts of supply chain - the leagile supply chain.

Characteristics of the metrics (Figure 3) are also changing; lean-oriented metrics are focused more on internal processes and on products, cost and productivity; as a result metrics are tangible and are given as financial value, cost or time. Such metrics are possible to be calculated using internal company data collected from process measurement and accounting systems. On the opposite scale are agile-related metrics - those are frequently softer, intangible, more difficult to capture within organization, as they require analysis of the views of suppliers and customers. Agile-related performance is harder to control as it relies on changes in external environment, the market and changes in customer needs. Common for both lean and agile metrics could be a combination of hard, internal metrics, possible to be measured by organization (quality of products and services, time); however, this also requires the comparison of the customer perception to monitor how time quality and customer service delivered are perceived by customers. Service/lead time, quality and customer service levels offered by organization should match those expected by customers. Adopting metrics from lean and agile is possible to measure leagile supply chain. 


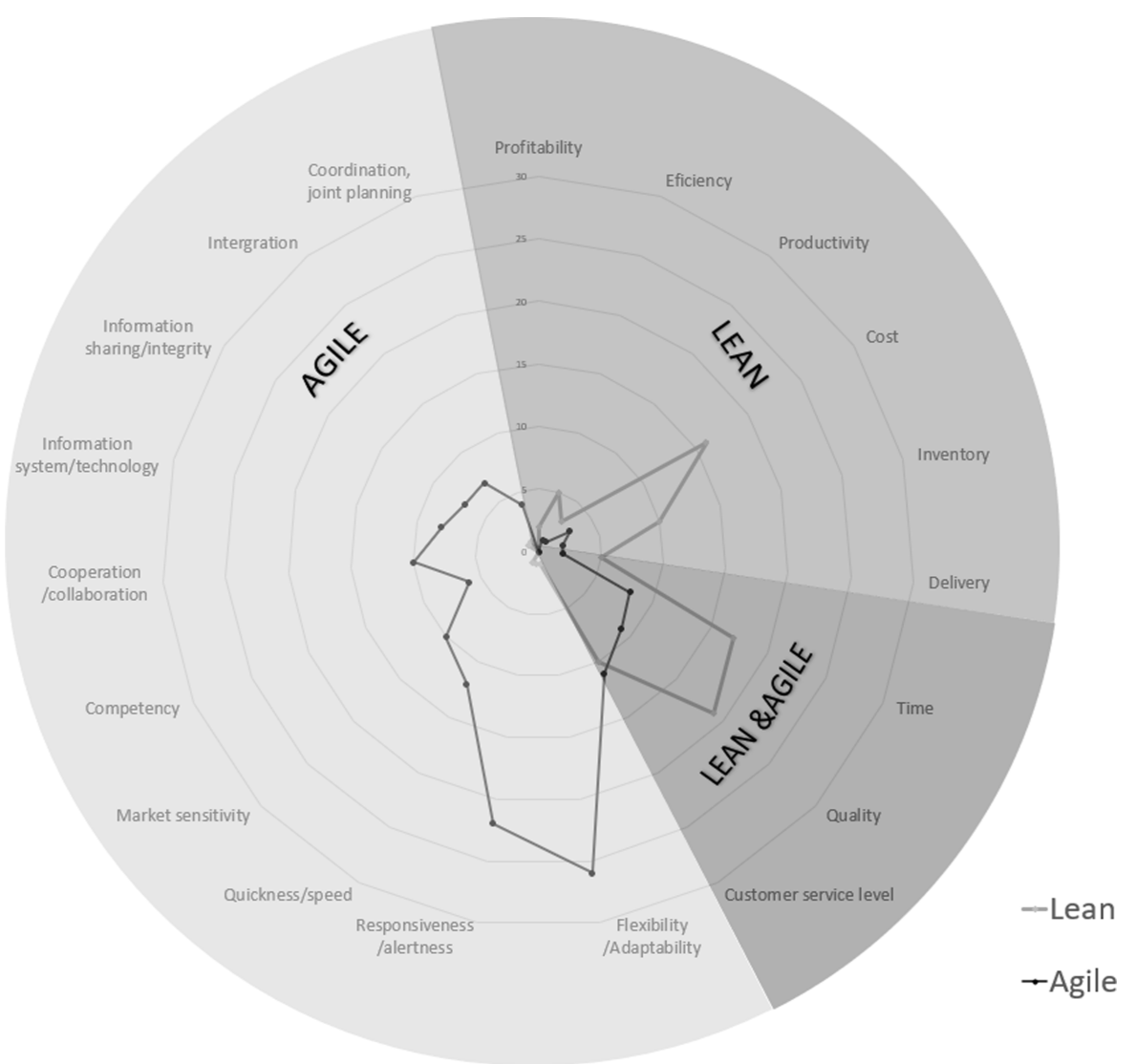

Framework for measuring leagile supply chain

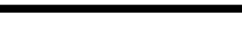

The selection of metrics to measure, monitor and assess supply chain performance is determined by strategy, processes and external environment (context), which is summarized in the framework that illustrates links between, lean, agile and leagile (Figure 3).

According to Qi et al. (2009), lean and agile strategies always complement each other. As Fadaki et al. (2019) stressed, all supply chains are in fact leagile, with different magnitudes of leanness and agility, and measurement should comprise a spectrum between the extremes of purely lean and purely agile supply chain, with a mid-point representing a leagile supply chain, whereby attention to both leanness and agility of a chain will result in larger profits. Borgström and Hertz (2011, p. 364) indicate that "pure lean and agile strategies have constraints in a complex setting" and, as supply chains change over time, sometimes it is necessary to shift the strategic focus.

Kisperska-Moron and De Haan (2011) concluded that it is hard to find "pure" lean or agile system, and companies are pursuing a mix of both approaches, additionally adjusting them to current market conditions. Some authors believe that lean strategy is a phase that may lead to agility (Mason-Jones, 2000; Madhani, 2017; Narasimhan et al., 2006), or that it is a necessary prelude to agility (Jin-Hai et al., 2003). Lean strategy efficiency "has to be supplemented with agility" in the contexts of short response times, high product and service variety (van Hoek et al., 2001). According to Aitken et al. (2005), "while leanness may be an element of agility in 


\section{IJPPM}

Figure 3.

Framework for measuring leagile supply chain performance

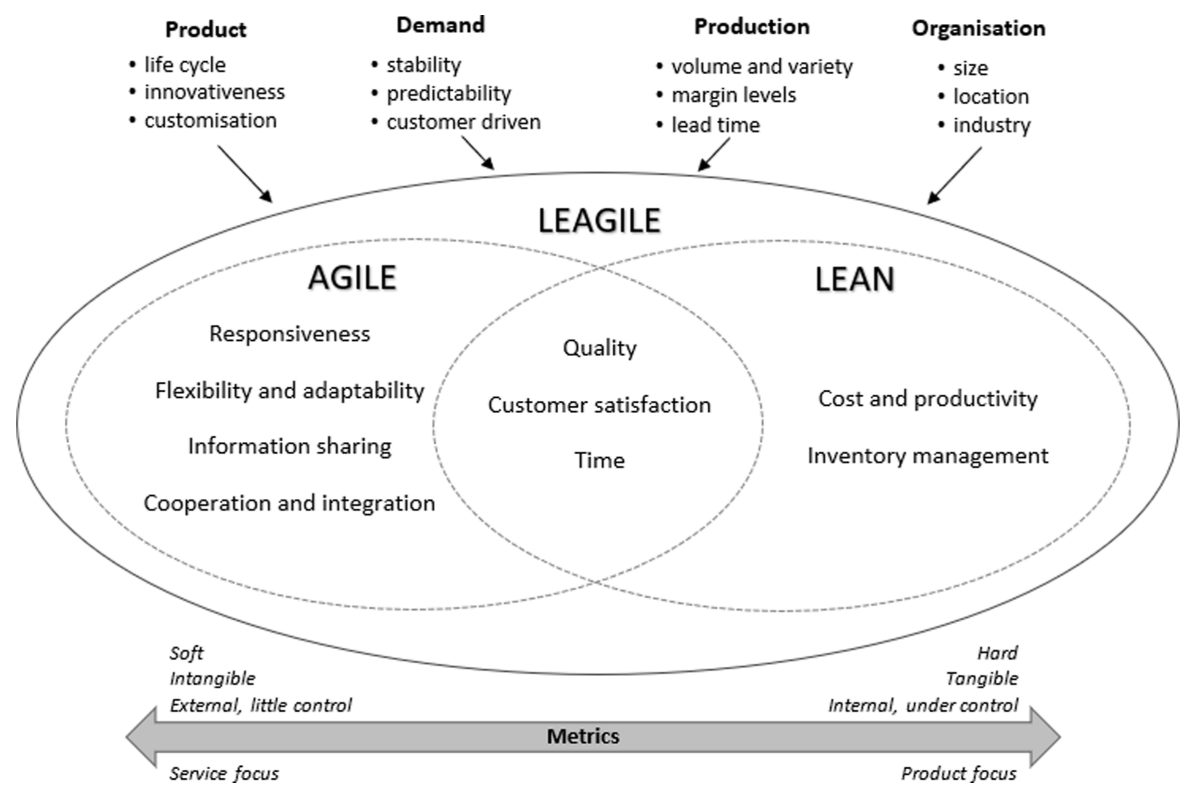

certain circumstances, by itself it will not enable the organization to meet the precise the needs of the customer more rapidly".

\section{Conclusions and future research}

This paper, based on literature review, analysed and synthesized knowledge related to lean, agile and leagile supply chain performance metrics. Performance measurement should be able to reflect and monitor performance and strategy implementation. The selection of metrics to measure, monitor and assess supply chain performance is determined by strategy, processes and external environment (context), which is summarized in the framework that illustrates links between, lean, agile and leagile.

The most meaningful and associated with lean strategy is set of metrics related to cost and inventory management and further linked to the assessment of profitability, productivity, efficiency and delivery. In case of agile strategy, the most common are metrics related to the assessment of supply chain flexibility or adaptability, its alertness and responsiveness. Flexibility is defined by Beamon (1999) as ability to change delivery, product mix and volumes. The noticeable is also the need to include in the measurement system metrics related to information sharing, coordination, process integration and level of cooperation in supply chain.

This paper is extending the knowledge on supply chain performance measurement, identifying the main metrics that are applicable in the lean, agile and leagile strategy. The paper contributes to theory by analysing and summarizing previous research and proposing the theoretical framework for measuring lean, agile and leagile supply chain. The framework could be tested using empirical data; it could be also applied in practice.

\subsection{Practical implications}

The framework proposed in this paper presents the set of key metrics for leagile supply chain, which could be used as starting point to design organizational and then supply chain 
performance system. However, in each case there is need to adjust detailed metrics to external environment. Findings also indicate that it is possible for organizations to merge both strategies, agile and lean, matching them with their customers and products, then monitor performance. In the single supply chain different companies are frequently using different performance metrics, the use of the joint metrics, as indicated in the framework, will allow to monitor end-to-end supply chain performance, also in the situation when within the same supply chain some companies are applying lean, other agile strategy.

\subsection{Limitations and future research}

This work is based on literature review without empirical research, which is shortcoming. Moreover, there is a limited number of papers published that are presenting leagile metrics in detail. Within papers included in the review also were those which were discussing performance at generic level, as performance criteria, not measures that can be applied in practice. From the review also "grey" literature, such as commercial and industrial reports and commercial performance measurement solutions were excluded. To validate the framework and metrics, further research should test and adjust proposed solution, applying both approach for an in-depth analysis of selected chains. Future studies could be designed as comparative cross-case analysis. There are several dimensions that could be used: looking at different industries, e.g. automotive (associated with lean design) versus fast fashion (agile) or the comparison of manufacturing versus services or different process designs (from projects, via batch to mass production), agility and lean could be also studied in the non-commercial settings, such as humanitarian logistics (immediate response vs reconstruction disaster management cycle phases). As the performance metrics and strategy selection are influenced by external context, further work should investigate such linkage, e.g. applying contingency theory. Another option is to employ a quantitative approach, where a large-scale survey could be used to look at performance metrics, strategy, product, environment and relationships between them. Systems dynamics models could be applied to look at interrelation between all variables.

\section{References}

Afonso, H. and do Rosário Cabrita, M. (2015), "Developing a lean supply chain performance framework in a SME: a perspective based on the balanced scorecard", Procedia Engineering, Vol. 131, pp. 270-279.

Agarwal, A., Shankar, R. and Tiwari, M.K. (2006), "Modeling the metrics of lean, agile and leagile supply chain: an ANP-based approach", European Journal of Operational Research, Vol. 173 No. 1, pp. 211-225.

Ahn, H.J., Chiderhouse, P., Vossen, G. and Lee, H. (2012), "Rethinking XML-enabled agile supply chains", International Journal of Information Management, Vol. 32 No. 1, pp. 17-23.

Aitken, J., Childerhouse, P., Christopher, M. and Towill, D. (2005), "Designing and managing multiple pipelines", Journal of Business Logistics, Vol. 26, pp. 73-96.

Aitken, J., Childerhouse, P. and Towill, D. (2003), "The impact of product life cycle on supply chain strategy", International Journal of Production Economics, Vol. 85 No. 2, pp. 127-140.

Akyuz, G.K. and Erkan, T.E. (2009), "Supply chain performance measurement: a literature review", International Journal of Production Research, Vol. 48 No. 17, pp. 1-19.

Al Kahtani, M., Rehman, A.U., Al-Zabidi, A. and Choudhary, A. (2019), "Agile supply chain assessment: an empirical study on concepts, research and issues", Arabian Journal for Science and Engineering, Vol. 44, pp. 2551-2565.

Arif-Uz-Zaman, K. and Nazmul Ahsan, A.M.M. (2014), "Lean supply chain performance measurement", International Journal of Productivity and Performance Management, Vol. 63 No. 5, pp. 588-612. 
Arlbjørn, J.S. and Freytag, P.V. (2013), "Evidence of lean: a review of international peer-reviewed journal articles", European Business Review, Vol. 25 No. 2, pp. 174-205.

Aronsson, H., Abrahamsson, M. and Spens, K. (2011), "Developing lean and agile health care supply chains”, Supply Chain Management, Vol. 16 No. 3, pp. 176-183, doi: 10.1108/ 13598541111127164.

Backhouse, C. and Burns, N. (1999), "Agile value chains for manufacturing-implications for performance measures", International Journal of Agile Management Systems, Vol. 1 No. 2, pp. $76-82$.

Balfaqih, H., Nopiah, Z.M., Saibani, N. and Al-Nory, M.T. (2016), "Review of supply chain performance measurement systems: 1998-2015”, Computers in Industry, Vol. 82, pp. 135-150.

Banerjee, A. and Ganjeizadeh, F. (2017), "Modeling a leagility index for supply chain sustenance", Procedia Manufacturing, Vol. 11, pp. 996-1003.

Beamon, B.M. (1999), "Measuring supply chain performance", International Journal of Operations and Production Management, Vol. 19 Nos 3-4, pp. 275-292.

Bernardes, E.S. and Hanna, M.D. (2009), "A theoretical review of flexibility, agility and responsiveness in the operations management literature: toward a conceptual definition of customer responsiveness", International Journal of Operations and Production Management, Vol. 29 No. 1, pp. 30-53.

Birhanu, D., Lanka, K. and Rao, A.N. (2014), "A survey of classifications in supply chain strategies”, Procedia Engineering, Vol. 97, pp. 2289-2297.

Borgström, B. and Hertz, S. (2011), "Supply chain strategies: changes in customer order-based production", Journal of Business Logistics, Vol. 32, pp. 361-373.

Braunscheidel, M.J. and Suresh, N.C. (2009), “The organizational antecedents of a firm's supply chain agility for risk mitigation and response", Journal of Operations Management, Vol. 27 No. 2, pp. 119-140.

Brown, J.L. and Agnew, N.M. (1982), “Corporate agility”, Business Horizons, Vol. 25 No. 2, pp. 29-33.

Bruce, M., Daly, L. and Towers, N. (2004), "Lean or agile: a solution for supply chain management in the textiles and clothing industry?", International Journal of Operations and Production Management, Vol. 24 No. 2, pp. 151-170.

Carvalho, H. and Cruz-Machado, V. (2011), "Integrating lean, agile, resilience and green paradigms in supply chain management (LARG_SCM)", Supply Chain Management, IntechOpen, pp. 27-48.

Chan, F.T.S. and Qi, H.J. (2003), "An innovative performance measurement method for supply chain management”, Supply Chain Management: An International Journal, Vol. 8 No. 3, pp. 209-223.

Chan, F.T.S., Qi, H.J., Chan, H.K., Lau, H.C.W. and Ip, R.W.L. (2003), "A conceptual model of performance measurement for supply chains", Management Decision, Vol. 41 No. 7, pp. 635-642.

Christopher, M. (2000), “The agile supply chain: competing in volatile markets", Industrial Marketing Management, Vol. 29, pp. 37-44.

Christopher, M., Lowson, R. and Peck, H. (2004), "Creating agile supply chains in the fashion industry", International Journal of Retail and Distribution Management, Vol. 32 No. 8, pp. 367-376, doi: 10.1108/09590550410546188.

Christopher, M., Peck, H. and Towill, D. (2006), "A taxonomy for selecting global supply chain strategies”, The International Journal of Logistics Management, Vol. 17 No. 2, pp. 277-287.

Christopher, M. and Towill, D.R. (2000), "Supply chain migration from lean and functional to agile and customised”, Supply Chain Management: An International Journal, Vol. 5 No. 4, pp. 206-213.

Christopher, M. and Towill, D.R. (2001), "An integrated model for the design of agile supply chains", International Journal of Physical Distribution and Logistics Management, Vol. 31 No. 4, pp. 235-246, doi: 10.1108/09600030110394914. 
Ciccullo, F., Pero, M., Caridi, M., Gosling, J. and Purvis, L. (2018), "Integrating the environmental and social sustainability pillars into the lean and agile supply chain management strategies: a literature review and future research directions", Journal of Cleaner Production, Vol. 172, pp. 2336-2350.

Costantino, N., Dotoli, M., Falagario, M., Fanti, M.P. and Mangini, A.M. (2012), "A model for supply management of agile manufacturing supply chains", International Journal of Production Economics, Vol. 135 No. 1, pp. 451-457.

Cuthbertson, R. and Piotrowicz, W. (2011), "Performance measurement systems in supply chains: a framework for contextual analysis", International Journal of Productivity and Performance Management, Vol. 60 No. 6, pp. 583-602.

Eckstein, D., Goellner, M., Blome, C. and Henke, M. (2015), "The performance impact of supply chain agility and supply chain adaptability: the moderating effect of product complexity", International Journal of Production Research, Vol. 53 No. 10, pp. 3028-3046.

Elrod, C., Murray, S.P.E. and Bande, S. (2013), "A review of performance metrics for supply chain management”, Engineering Management Journal, Vol. 25 No. 3, pp. 39-50.

Fadaki, M., Rahman, S. and Chan, C. (2019), "Quantifying the degree of supply chain leagility and assessing its impact on firm performance", Asia Pacific Journal of Marketing and Logistics, Vol. 31 No. 1, pp. 246-264.

Fayezi, S., Zutshi, A. and O'Loughlin, A. (2017), "Understanding and development of supply chain agility and flexibility: a structured literature review", International Journal of Management Reviews, Vol. 19 No. 4, pp. 379-407, doi: 10.1111/ijmr.12096.

Fening, F.A., Pesakovic, G. and Amaria, P. (2008), "Relationship between quality management practices and the performance of small and medium size enterprises (SMEs) in Ghana", International Journal of Quality and Reliability Management, Vol. 25 No. 7, pp. 694-708.

Fisher, M.L. (1997), "What is the right supply chain for your product?", Harvard Business Review, Vol. 75, pp. 105-117.

Frazzon, E., Tortorella, G.L., Dávalos, R., Holtz, T. and Coelho, L. (2017), "Simulation-based analysis of a supplier-manufacturer relationship in lean supply chains", International Journal of Lean Six Sigma, Vol. 8 No. 3, pp. 262-274, doi: 10.1108/IJLSS-03-2016-0009.

Fullerton, R.R. and Wempe, W.F. (2009), "Lean manufacturing, non-financial performance measures, and financial performance", International Journal of Operations and Production Management, Vol. 29 No. 3, pp. 214-240.

Gligor, D.M., Esmark, C.L. and Holcomb, M.C. (2015), "Performance outcomes of supply chain agility: when should you be agile?", Journal of Operations Management, Vols 33-34, pp. 71-82.

Gligor, D.M. and Holcomb, M.C. (2012), "Understanding the role of logistics capabilities in achieving supply chain agility: a systematic literature review", Supply Chain Management: An International Journal, Vol. 17 No. 4, pp. 438-453.

Gligor, D., Holcomb, M. and Stank, T. (2013), "A multidisciplinary approach to supply chain agility: conceptualization and scale development”, Journal of Business Logistics, Vol. 34 No. 2, pp. 94-108, doi: 10.1111/jbl.12012.

Goldsby, T.J., Griffis, S.E. and Roath, A.S. (2006), "Modeling lean, agile, and leagile supply chain strategies", Journal of Business Logistics, Vol. 27 No. 1, pp. 57-80.

Gopal, P. and Thakkar, J. (2012), "A review on supply chain performance measures and metrics: 20002011", International Journal of Productivity and Performance Management, Vol. 61 No. 5, pp. 518-547.

Govindan, K., Azevedo, S.G., Carvalho, H. and Cruz-Machado, V. (2015), "Lean, green and resilient practices influence on supply chain performance: interpretive structural modeling approach", International Journal of Environmental Science and Technology, Vol. 12, pp. 15-34.

Gunasekaran, A. (1999), "Agile manufacturing: a framework for research and development", International Journal of Production Economics, Vol. 62 No. 1, pp. 87-105. 
Gunasekaran, A. and Kobu, B. (2007), "Performance measures and metrics in logistics and supply chain management: a review of recent literature (1995-2004) for research and applications", International Journal of Production Research, Vol. 45 No. 12, pp. 2819-2840.

Gunasekaran, A., Patel, C. and Tirtiroglu, E. (2001), "Performance measures and metrics in a supply chain environment", International Journal of Operations and Production Management, Vol. 21 Nos 1-2, pp. 71-87.

Gurahoo, N. and Salisbury, R.H. (2018), "Lean and agile in small- and medium-sized enterprises: complementary or incompatible”, South African Journal of Business Management, Vol. 49 No. 1.

Hines, P., Holweg, M. and Rich, N. (2004), "Learning to evolve: a review of contemporary lean thinking", International Journal of Operations and Production Management, Vol. 24 No. 10, pp. 994-1011.

Holweg, M. (2007), “The genealogy of lean production”, Journal of Operations Management, Vol. 25 No. 2, pp. 420-437.

Huang, Y.-Y. and Li, S.-J. (2009), "Tracking the evolution of research issues on agility”, Asia Pacific Management Review, Vol. 14 No. 1, pp. 107-129.

Jain, V., Benyoucef, L. and Deshmukh, S.G. (2008), "What's the buzz about moving from 'lean'to 'agile'integrated supply chains? A fuzzy intelligent agent-based approach", International Journal of Production Research, Vol. 46 No. 23, pp. 6649-6677, doi: 10.1080/00207540802230462.

Jasti, N.V.K. and Kodali, R. (2015), "A critical review of lean supply chain management frameworks: proposed framework", Production Planning and Control, Vol. 26 No. 13, pp. 1051-1068.

Jin-Hai, L., Anderson, A.R. and Harrison, R.T. (2003), "The evolution of agile manufacturing”, Business Process Management Journal, Vol. 9 No. 2, pp. 170-189, doi: 10.1108/14637150310468380.

Kennerley, M. and Neely, A. (2002), "A framework of the factors affecting the evolution of performance measurement systems", International Journal of Operations and Production Management, Vol. 22 No. 11, pp. 1222-1245.

Khalili-Damghani, K. and Tavana, M. (2013), "A new fuzzy network data envelopment analysis model for measuring the performance of agility in supply chains", The International Journal of Advanced Manufacturing Technology, Vol. 69, pp. 291-318.

Khan, K.A., Bakkappa, B., Metri, B.A. and Sahay, B.S. (2009), "Impact of agile supply chains' delivery practices on firms' performance: cluster analysis and validation”, Supply Chain Management, Vol. 14 No. 1, pp. 41-48.

Kim, K.K., Umanath, N.S., Kim, J.Y., Ahrensc, F. and Kim, B. (2012), "Knowledge complementarity and knowledge exchange in supply channel relationships", International Journal of Information Management, Vol. 32, pp. 35-49.

Kisperska-Moron, D. and De Haan, J. (2011), "Improving supply chain performance to satisfy final customers: 'leagile' experiences of a polish distributor", International Journal of Production Economics, Vol. 133 No. 1, pp. 127-134.

Kisperska-Moron, D. and Swierczek, A. (2009), "The agile capabilities of polish companies in the supply chain: an empirical study", International Journal of Production Economics, Vol. 118, pp. $217-224$.

Krafcik, J.F. (1988), "Triumph of the lean production system”, Sloan Management Review, Vol. 30 No. 1, pp. 41-51.

Kuhlang, P., Edtmayr, T. and Sihn, W. (2011), "Methodical approach to increase productivity and reduce lead time in assembly and production-logistic processes", CIRP Journal of Manufacturing Science and Technology, Vol. 4 No. 1, pp. 24-32.

Kumar, M., Garg, D. and Agarwal, A. (2019), "Cause and effect analysis of inventory management in leagile supply chain”, Journal of Management Information and Decision Sciences, Vol. 22, p. 67.

Lambert, D. and Pohlen, T. (2001), "Supply chain metrics", International Journal of Logistics Management, Vol. 12 No. 1, pp. 1-19. 
Li, X., Chung, C., Goldsby, T.J. and Holsapple, C.W. (2008), "A unified model of supply chain agility: the work-design perspective", International Journal of Logistics Management, Vol. 19 No. 3, pp. 408-435.

Li, X., Goldsby, T.J. and Holsapple, C.W. (2009), "Supply chain agility: scale development", International Journal of Logistics Management, Vol. 20 No. 2, pp. 408-424.

Framework for measuring leagile supply chain

Lin, C.-T., Chiu, H. and Chu, P.-Y. (2006), "Agility index in the supply chain", International Journal of Production Economics, Vol. 100 No. 2, pp. 285-299.

Madhani, P.M. (2017), "Supply chain strategy selection: a multi-criteria decision-making approach", The IUP Journal of Supply Chain Management, Vol. 14 No. 2, pp. 38-56.

Maestrini, V., Luzzini, D., Caniato, F., Maccarrone, P. and Ronchi, S. (2018), "Measuring supply chain performance: a lifecycle framework and a case study", International Journal of Operations and Production Management, Vol. 38 No. 4, pp. 934-956.

Maestrini, V., Luzzini, D., Maccarrone, P. and Caniato, F. (2017), "Supply chain performance measurement systems: a systematic review and research agenda", International Journal of Production Economics, Vol. 183, pp. 299-315.

Malmbrandt, M. and Åhlström, P. (2013), “An instrument for assessing lean service adoption”, International Journal of Operations and Production Management, Vol. 33 No. 9, pp. 1131-1165.

Marodin, G.A., Tortorella, G.L., Frank, A.G. and Godinho Filho, M. (2017), "The moderating effect of lean supply chain management on the impact of lean shop floor practices on quality and inventory", Supply Chain Management, Vol. 22 No. 6, pp. 473-485.

Mason-Jones, R., Naylor, B. and Towill, D.R. (2000a), "Engineering the leagile supply chain", International Journal of Agile Management Systems, Vol. 2 No. 1, pp. 54-61.

Mason-Jones, R., Naylor, B. and Towill, D.R. (2000b), "Lean, agile or leagile? Matching your supply chain to the marketplace", International Journal of Production Research, Vol. 38 No. 17, pp. 4061-4070.

Matawale, C.R., Datta, S. and Mahapatra, S.S. (2016), "Supplier selection in agile supply chain: application potential of FMLMCDM approach in comparison with fuzzy-TOPSIS and fuzzyMOORA", Benchmarking: An International Journal, Vol. 23 No. 7, pp. 2027-2060, doi: 10.1108/ BIJ-07-2015-0067.

Meade, D., Kumar, S. and White, B. (2010), "Analysing the impact of the implementation of lean manufacturing strategies on profitability”, Journal of the Operational Research Society, Vol. 61 No. 5, pp. 858-871.

Mehralian, G., Zarenezhad, F. and Rajabzadeh Ghatari, A. (2015), "Developing a model for an agile supply chain in pharmaceutical industry", International Journal of Pharmaceutical and Healthcare Marketing, Vol. 9 No. 1, pp. 74-91, doi: 10.1108/IJPHM-09-2013-0050.

Melnyk, A.S., Steward, D.M. and Swink, M. (2004), "Metrics and performance measurement in operations management: dealing with the metrics maze", Journal of Operations Management, Vol. 22 No. 3, pp. 209-217.

Melton, T. (2005), "The benefits of lean manufacturing: what lean thinking has to offer the process industries", Chemical Engineering Research and Design, Vol. 83 No. 6, pp. 662-673.

Mirghafoori, S.H., Andalib, D. and Keshavarz, P. (2017), "Developing green performance through supply chain agility in manufacturing industry: a case study approach", Corporate Social Responsibility and Environmental Management, Vol. 24 No. 5, pp. 368-381.

Morgan, C. (2004), "Structure, speed and salience: performance measurement in the supply chain", Business Process Management Journal, Vol. 10 No. 5, pp. 522-536.

Moyano-Fuentes, J. and Sacristán-Díaz, M. (2012), "Learning on lean: a review of thinking and research", International Journal of Operations and Production Management, Vol. 32 No. 5, pp. 551-582. 
Naim, M.M. and Gosling, J. (2011), "On leanness, agility and leagile supply chains”, International Journal of Production Economics, Vol. 131 No. 1, pp. 342-354.

Narasimhan, R., Swink, M. and Kim, S.W. (2006), "Disentangling leanness and agility: an empirical investigation”, Journal of Operations Management, Vol. 24 No. 5, pp. 440-457.

Naylor, J.B., Naim, M.M. and Berry, D. (1999), "Leagility: integrating the lean and agile manufacturing strategies in the total supply chain", International Journal of Production Economics, Vol. 62 No. 1, pp. 107-118.

Neely, A. (2005), "The evolution of performance measurement research. Developments in the last decade and a research agenda for the next", International Journal of Operations and Production Management, Vol. 25 No. 1, pp. 1264-1277.

Neely, A., Gregory, M. and Platts, K. (1995), "Performance measurement system design: a literature review and research agenda", International Journal of Operations and Production Management, Vol. 15 No. 4, pp. 80-116.

Okoli, C. (2015), "A guide to conducting a standalone systematic literature review", Communications of the Association for Information Systems, Vol. 37, pp. 879-910.

Packowski, J. and Francas, D. (2013), "Lean SCM : a paradigm shift in supply chain management", Journal of Business Chemistry, Vol. 10 No. 3, pp. 131-213.

Patel, B.S., Samuel, C. and Sharma, S.K. (2017), "Evaluation of agility in supply chains: a case study of an Indian manufacturing organization", Journal of Manufacturing Technology Management, Vol. 28 No. 2, pp. 212-231, doi: 10.1108/JMTM-09-2016-0125.

Piotrowicz, W. and Cuthbertson, R. (2015), "Performance measurement and metrics in supply chains: an exploratory study", International Journal of Productivity and Performance Management, Vol. 64 No. 8, pp. 1068-1091.

Qi, Y., Boyer, K.K. and Zhao, X. (2009), "Supply chain strategy, product characteristics, and performance impact: evidence from Chinese manufacturers", Decision Sciences, Vol. 40, pp. 667-695.

Rahimi, A., Raad, A., Alem Tabriz, A. and Motameni, A. (2020), "Providing an interpretive structural model of agile supply chain practices", Journal of Modelling in Management, Vol. 15 No. 2, pp. 661-684, doi: 10.1108/JM2-09-2018-0142.

Rahiminezhad Galankashi, M. and Helmi, S.A. (2016), "Assessment of hybrid lean-agile (leagile) supply chain strategies", Journal of Manufacturing Technology Management, Vol. 27 No. 4, pp. 470-482, doi: 10.1108/JMTM-08-2015-0069.

Rimienè, K. (2011), "Supply chain agility concept evolution (1990-2010)”, Economics and Management, Vol. 16, pp. 892-899.

Saeed, K.A., Malhotra, M.K. and Abdinnour, S. (2019), "How supply chain architecture and product architecture impact firm performance: an empirical examination", Journal of Purchasing and Supply Management, Vol. 25 No. 1, pp. 40-52.

Sangwa, N.R. and Sangwan, K.S. (2018), "Development of an integrated performance measurement framework for lean organizations", Journal of Manufacturing Technology Management, Vol. 29 No. 1, pp. 41-84.

Schmitz, J. and Platts, K. (2004), "Supplier logistics performance measurement: indications from a study in the automotive industry", International Journal of Production Economics, Vol. 89 No. 2, pp. 231-243.

Shepherd, C. and Gunter, H. (2006), "Measuring supply chain: current research and future directions", International Journal of Productivity and Performance Management, Vol. 55 Nos 3/4, pp. 242-258.

Simatupang, T.M. and Sridharan, R. (2008), "Design for supply chain collaboration”, Business Process Management Journal, Vol. 14 No. 3, pp. 401-418, doi: 10.1108/14637150810876698.

Stone, K.B. (2012), "Four decades of lean: a systematic literature review", International Journal of Lean Six Sigma, Vol. 3 No. 2, pp. 112-132. 
Sukwadi, R., Wee, H.-M. and Yang, C.-C. (2013), "Supply chain performance based on the lean-agile operations and supplier-firm partnership: an empirical study on the garment industry in Indonesia”, Journal of Small Business Management, Vol. 51, pp. 297-311.

Swafford, P.M., Ghosh, S. and Murthy, N. (2008), "Achieving supply chain agility through IT integration and flexibility", International Journal of Production Economics, Vol. 116 No. 2, pp. 288-297.

Szymczak, M., Ryciuk, U., Leończuk, D., Piotrowicz, W., Witkowski, K., Nazarko, J. and Jakuszewicz, J. (2018), "Key factors for information integration in the supply chain - measurement, technology and information characteristics", Journal of Business Economics and Management, Vol. 19 No. 5, pp. 759-776.

Tarafdar, M. and Qrunfleh, S. (2017), "Agile supply chain strategy and supply chain performance: complementary roles of supply chain practices and information systems capability for agility", International Journal of Production Research, Vol. 55 No. 4, pp. 925-938.

Taticchi, P., Tonelli, F. and Cagnazzo, L. (2010), "Performance measurement and management: a literature review and a research agenda", Measuring Business Excellence, Vol. 14 No. 1 , pp. 4-18.

Thanki, S. and Thakkar, J. (2018), “A quantitative framework for lean and green assessment of supply chain performance", International Journal of Productivity and Performance Management, Vol. 67 No. 2, pp. 366-400.

Tortorella, G.L., Giglio, R. and Limon-Romero, J. (2018), "Supply chain performance: how lean practices efficiently drive improvements", Journal of Manufacturing Technology Management, Vol. 29 No. 5, pp. 829-845, doi: 10.1108/JMTM-09-2017-0194.

Ugochukwu, P., Engström, J. and Langstrand, J. (2012), "Lean in the supply chain: a literature review”, Management and Production Engineering Review, Vol. 3 No. 4, pp. 87-96.

van Hoek, R.I., Harrison, A. and Christopher, M. (2001), "Measuring agile capabilities in the supply chain", International Journal of Operations and Production Management, Vol. 21 Nos 1/2, pp. 126-148.

Wang, G., Huang, S.H. and Dismukes, J.P. (2004), "Product-driven supply chain selection using integrated multi-criteria decision-making methodology", International Journal of Production Economics, Vol. 91 No. 1, pp. 1-15.

Wee, H.M. and Wu, S. (2009), "Lean supply chain and its effect on product cost and quality: a case study on Ford Motor Company", Supply Chain Management, Vol. 14 No. 5, pp. 335-341.

Womack, J.P., Jones, D.T. and Roos, D. (1990), The Machine that Changed the World, Simon and Schuster, New York.

Wu, I.-L., Chuang, C.-H. and Hsu, C.-H. (2014), "Information sharing and collaborative behaviors in enabling supply chain performance: a social exchange perspective", International Journal of Production Economics, Vol. 148, pp. 122-132.

Wu, K.J., Tseng, M.-L., Chiu, A.S.F. and Lim, M.K. (2017), "Achieving competitive advantage through supply chain agility under uncertainty: a novel multi-criteria decision-making structure", International Journal of Production Economics, Vol. 190, pp. 96-107.

Yang, Z. and Zhang, L. (2013), "Information sharing in supply chain: a review", Journal of Digital Information Management, Vol. 11 No. 2, pp. 125-130.

Yusuf, Y., Adeleye, E. and Sivayoganathan, K. (2003), "Volume flexibility: the agile manufacturing conundrum", Management Decision, Vol. 41 No. 7, pp. 613-624.

Yusuf, Y.Y., Gunasekaran, A., Musa, A., Dauda, M., El-Berishy, N.M. and Cang, S. (2014), “A relational study of supply chain agility, competitiveness and business performance in the oil and gas industry”, International Journal of Production Economics, Vol. 147, pp. 531-543.

Yusuf, Y.Y., Sarhadi, M. and Gunasekaran, A. (1999), "Agile manufacturing: the drivers, concepts and attributes”, International Journal of Production Economics, Vol. 62 No. 1, pp. 33-43. 
Zhang, Z. and Sharifi, H. (2000), "A methodology for achieving agility in manufacturing organisations", International Journal of Operations and Production Management, Vol. 20 No. 4 , pp. 496-513.

\section{About the authors}

Wojciech Domink Piotrowicz (PhD Brunel, UK, MA Gdańsk, Poland, PGDipLATHE Oxon, UK) is Associate Professor in Supply Chain Management and Social Responsibility and Director of the Humanitarian Logistics and Supply Chain Research Institute (HUMLOG Institute) at Hanken School of Economics, Helsinki, Finland. His research is related to technology and supply chain management, humanitarian logistics, performance measurement and evaluation. Wojciech has considerable experience as member of large international research projects within both the public and private sectors. He is recipient of Outstanding and Highly Commended paper awards from Emerald Literati Network for Excellence. Wojciech Domink Piotrowicz is the corresponding author and can be contacted at:wojciech.piotrowicz@hanken.fi

Urszula Ryciuk, $\mathrm{PhD}$ is an Assistant Professor in International Department of Logistics and Service Engineering at the Engineering Management Faculty of Bialystok University of Technology, Poland. Received her $\mathrm{PhD}$ in economics, specialization in science of management, in 2014 at Gdańsk University of Technology. Her research interests are logistics, supply chain management, interorganizational relationships, trust management and statistic data analysis. She is the author (co-author) of nearly 50 publications in the field of management and is the coordinator and researcher in international projects and grants of Polish National Science Centre.

Prof. Maciej Szymczak is Full Professor of Business Administration, Institute of International Business and Economics, Department of Logistics, Poznań University of Economics and Business (PUEB), Poznań, Poland. He received M.Sc. in the area of Computer Science from the Technical University of Poznan, $\mathrm{PhD}$ and post $\mathrm{PhD}$ in the area of Business Administration, majoring in business logistics management, from PUEB. His research focuses on business logistics, international logistics and supply chain management, information systems for logistics and city logistics. He has published over 120 articles in professional journals. He is author and co-author or editor of 17 books.

For instructions on how to order reprints of this article, please visit our website:

www.emeraldgrouppublishing.com/licensing/reprints.htm

Or contact us for further details: permissions@emeraldinsight.com 